\title{
The main aspects of distance education for students in times of epidemic restrictions
}

\section{Os principais aspectos da educação a distância para alunos em tempos de restrição epidêmica}

\section{Los principales aspectos de la educación a distancia para los estudiantes en tiempos de restricciones epidémicas}

\author{
Roma Sybirna $^{1}$ iD, Ganna Polishchuk ${ }^{2}$ iD Oleksandr Balanutsa $^{3}$ iD, Alla Marchuk $^{1}$ iD \\ ${ }^{1}$ Lviv State University of Internal Affairs, Lviv, Ukraine. \\ ${ }^{2}$ Volodymyr Vynnychenko Central Ukrainian State Pedagogical University, Kropyvnytskyi, Ukraine. \\ ${ }^{3}$ Ukraine to the State of Kuwait, Lviv, Ukraine. \\ Corresponding author: \\ Roma Sybirna \\ Email: journaltm@ukr.net
}

How to cite: Sybirna, R., Polishchuk, G., Balanutsa, O., \& Marchuk, A. (2022). The main aspects of distance education for students in times of epidemic restrictions. Revista Tempos e Espaços em Educação, 15(34), e16906.

http://dx.doi.org/10.20952/revtee.v15i34.16906

\section{ABSTRACT}

The new conditions that the entire world community faced in 2020, associated with the announcement by the World Health Organization (WHO) of the coronavirus (COVID-19) pandemic, led to the complete transition of all educational organizations of the world to distance learning. Previously, only those students who chose this form upon admission were trained remotely. In the context of a pandemic, students of full-time, part-time, and part-time (non-distance) departments were forced to switch to this format. Naturally, this caused certain difficulties, both for teachers and students. However, the demand for an instant and, as it turned out, a long and universal transition to distance learning turned out to be very unexpected and problematic for many subjects of the educational space, both in higher education and in the middle level. Thus, the main purpose of article is to study the main aspects and features of the introduction of basic techniques and means of distance education during the period of pandemic restrictions. The study was carried out using the following theoretical methods: systems analysis and synthesis, induction and deduction, comparison, classification, generalization and systematization, idealization and abstraction.

Keywords: Distance education. Methods of teaching. Pandemic restrictions. Pedagogy. Students.

\section{RESUMO}

As novas condições que toda a comunidade mundial enfrentou em 2020, associadas ao anúncio da pandemia do coronavírus (COVID-19) pela Organização Mundial da Saúde (OMS), levaram à 
transição completa de todas as organizações educacionais do mundo para o ensino a distância. Anteriormente, apenas os alunos que escolhiam esse formulário no momento da admissão eram treinados remotamente. No contexto de uma pandemia, os alunos dos departamentos de tempo integral, parcial e parcial (não à distância) foram forçados a mudar para este formato. Naturalmente, isso causou algumas dificuldades, tanto para professores quanto para alunos. No entanto, a demanda por um instante e, como se verificou, uma longa e universal transição para o ensino a distância revelou-se muito inesperada e problemática para muitas disciplinas do espaço educacional, tanto no ensino superior como no nível médio. Assim, o objetivo principal da redação deste artigo é estudar os principais aspectos e características da introdução de técnicas e meios básicos de educação a distância durante o período de restrições pandêmicas. $O$ estudo foi realizado utilizando os seguintes métodos teóricos: análise e síntese de sistemas, indução e dedução, comparação, classificação, generalização e sistematização, idealização e abstração.

Palavras-chave: Alunos. Educação a distância. Métodos de ensino. Pedagogia. Restrições pandêmicas.

\section{RESUMEN}

Las nuevas condiciones que enfrentó toda la comunidad mundial en 2020, asociadas al anuncio por parte de la Organización Mundial de la Salud (OMS) de la pandemia del coronavirus (COVID-19), llevaron a la transición completa de todas las organizaciones educativas del mundo a la educación a distancia. Anteriormente, solo los estudiantes que eligieron este formulario al momento de la admisión fueron capacitados de forma remota. En el contexto de una pandemia, los estudiantes de departamentos de tiempo completo, medio tiempo y medio tiempo (no a distancia) se vieron obligados a cambiar a este formato. Naturalmente, esto provocó ciertas dificultades, tanto para los profesores como para los estudiantes. Sin embargo, la demanda de una transición instantánea y, como resultó, larga y universal a la educación a distancia resultó muy inesperada y problemática para muchas asignaturas del espacio educativo, tanto en la educación superior como en el nivel medio. Así, el propósito principal del artículo es estudiar los principales aspectos y características de la introducción de técnicas y medios básicos de educación a distancia durante el período de restricciones pandémicas. El estudio se llevó a cabo utilizando los siguientes métodos teóricos: análisis y síntesis de sistemas, inducción y deducción, comparación, clasificación, generalización y sistematización, idealización y abstracción.

Palabras clave: Educación a distancia. Estudiantes. Métodos de enseñanza. Pedagogía. Restricciones pandémicas.

\section{INTRODUCTION}

A condition for the development of today's education is digitalization and the widespread introduction of e-learning methods based on the use of modern telecommunication technologies. Distance education is considered as a new form of education, providing a range of educational services to the general population in our country and abroad using a specialized information and educational environment at any distance from educational institutions.

Living in conditions of severe restrictions associated with the pandemic, which led to selfisolation, imposes new and increased demands on the education sector. In this regard, an urgent need arose to determine the possibilities and boundaries of using the distance learning format. It is obvious that nowadays the online format is only a necessary tool for learning. However, the uncertainty and volatility of the world, according to the philosopher, historian and writer Yuval Noah Harari, makes increased demands on learning (Filipenko, 2016).

Many educators argue that schools need to move towards building four skills: critical thinking, communication, collaboration, and creativity. Most important will be the ability to adapt to change, learn new things, and stay cool in unfamiliar situations. With the acceleration of the pace 
of change, new innovative tools, for example, the distance format, will increasingly fill the educational process. The coronavirus pandemic, self-isolation and the associated distance learning are forcing global education to adapt to changes, to build a new methodology for a combined intramural and extramural online format (Ivanov, 2012).

In technical terms, there is a whole range of communication means for the teacher and student: computer programs, web technologies, videoconferences, educational materials on various electronic media. Hundreds of leading universities work on such programs, among them Penn State, University of Florida, University of Massachusetts, which have relatively large-scale distance programs. Stanford University, the University of Southern California (USC), Columbia University and Georgia Tech are the leaders in the number of students enrolled in distance master's programs in engineering (Burkina, 2014).

Researchers also note that developing technologies create risks of new barriers to the even development of different regions, countries, as well as increasing differentiation between different social strata.

As a result, the relevance of research on "digital competence" in education as an indicator of the development of new technologies used in the educational process by students and teachers is growing.

\section{METHODOLOGY}

The main purpose of the study is to analyze the main aspects and features of the implementation of the main methods and mechanisms of distance education in the modern realities of pandemic restrictions. In modern conditions, an important place is given to the integration of science, education and innovation. For this, a number of methods were applied that make up the research methodology. The research was carried out using the following theoretical methods: systems analysis and synthesis, induction and deduction, comparison, classification, generalization and systematization, idealization and abstraction.

\section{RESULTS AND DISCUSSION}

One of the main tasks of modern education is to train a specialist who is free to navigate in the global information space, knowledge and skills in searching, processing and storing information using modern computer technologies. Distance learning is designed to help the global educational space. It acts as an effective addition to traditional forms of education, as a means of partial solution of its urgent problems. This direction is considered promising, because education is characterized as a large system, the high-quality functioning of which is impossible without the use of modern telecommunication and computer storage, processing, transmission and presentation of information (Welch, 2001).

It should be noted that it is distance education that gives students access to non-traditional sources of information, increases the efficiency of independent work, provides completely new opportunities for creativity, finding and consolidating various professional skills, and allows teachers to implement fundamentally new forms and methods of teaching using conceptual modeling of phenomena. processes This form of organization of training will solve many problems in front of which other forms of education are powerless. Get a first or second higher education, improve your qualifications, exchange experience, get expert advice, actively participate in professional communication without leaving your family or work - these are the problems that concern a large number of citizens of any country.

Distance learning is a form of education using computer and telecommunication technologies that provide interactive interaction between teachers and students at different stages of training and independent work with the materials of the information network. This is an ideal 
solution for those who prefer modern information technologies in education and value their time. Distance learning gives students the opportunity to have round-the-clock access to educational materials, constant support and advice from teachers and methodologists, online video lectures, virtual simulators and other technological solutions to ensure an effective learning process.

It should be noted that distance learning is not antagonistic to full-time and part-time forms of education. It naturally integrates into these systems, complementing and developing them, which contributes to the creation of a mobile learning environment.

Until recently, in the world, distance learning was rather used as separate distance courses that did not provide complete training in a particular subject. It emerged and developed as a new type of learning on the demand of a new generation of students to support their needs. The quarantine measures introduced in March 2020 have become a significant challenge for the entire education system of the world. This atypical situation provided the conditions for an unplanned, large-scale, natural experiment in educational institutions, which made it possible to obtain an unexpected but very valuable experience. Experience when, in the absence of a choice, it was necessary to implement a key task - to move quickly to online training, but not to lose quality and avoid unnecessary financial burdens. The total introduction of distance learning, as the main form, revealed its unwillingness to completely replace traditional teaching, which prevailed in the educational process until recently (Ana et al, 2020).

Note that the distance learning system is by no means a way of replacing a teacher with a computer program, but a mode of interaction between students / listeners and a teacher on the basis of information and communication technologies.

The peculiarity of distance learning required the introduction into the educational reality of the definition of "tutor", whose functions are determined by the educational model, which is practiced by a certain distance learning system. Tutoring activities can be carried out both by fulltime teachers of higher education institutions and by persons of other professions, that is, everyone involved in the process of distance learning (on the terms of hourly wages or part-time work. students who determine their implementation of the following functions: the transfer of positive experience, the setting of good-quality goals and objectives, the correct formation of motives for learning, organizational activities, quality control of the learning process, competent organization of interaction between students (Arora, Srinivansen, 2020).

The main advantages of distance learning are shown in table 1 .

Table 1. The main advantages of distance learning.

\begin{tabular}{cl}
\hline Advantage & The essence \\
\hline Flexibility & $\begin{array}{l}\text { the ability to present the course material based on the training, the abilities of } \\
\text { the listeners } \\
\text { the possibility of introducing new pedagogical, psychological, methodological } \\
\text { developments } \\
\text { the ability to study at a convenient time, in a specific place, receive education } \\
\text { without interrupting the main job, no time limits for mastering the material } \\
\text { the division of the material into separate functionally complete topics, studied } \\
\text { as they are mastered and corresponding to the abilities of an individual listener } \\
\text { or a group as a whole } \\
\text { the teaching method is cheaper than the "traditional" one, thanks to the } \\
\text { efficient use of classrooms, facilitated correction of electronic teaching } \\
\text { materials and multi-access to them } \\
\text { active communication between the students of the group and the teacher, } \\
\text { Interactivity }\end{array}$ \\
$\begin{array}{l}\text { which significantly increases the motivation for learning, improves the } \\
\text { assimilation of the material }\end{array}$
\end{tabular}


An illustrative example of the effective use of distance learning technologies in higher education institutions is the use of MOOCs (Massive OpenOnlineCourses) - this is a modern educational modus that provides for the organization of huge open free educational online courses. In 2012, the majority of reputable universities on a global scale joined the MOOCs, which included in their training programs distance courses available to everyone (they operate free of charge). According to the initiators of the organization of online courses MOOCs, the newest approach to education will lead to a significant increase in the quality of education and its productivity, including for those students who usually receive knowledge in traditional (non-virtual) classrooms. MOOCs open up opportunities for students to choose, create a kind of dilemma: to be passive listeners for them (devoting only a few hours a week to study) or to be proactive participants (to actively deepen knowledge, listen to lectures, solve self-control tests). The academic week of MOOCs requires watching 2-4 short video lectures and after solving problems that provide mobile self-control.

Video lectures were created based on materials from online textbooks that are in the public domain - open in a virtual environment for each student. The authors of these textbooks are mainly the course tutors themselves, which leads to a deepening of the listener's interest, because later during the live meeting he will have the opportunity to ask questions. The study of the course ends with an online exam, the successful completion of which provides for the issuance of special certificates to students.

The prompt application of distance learning technologies guarantees higher education institutions (Volchik, 2019):

- a significant increase in the subjects of the educational process (organization of training for a wide audience - the simultaneous attraction of a large number of students);

- a significant reduction in the cost of organizing the educational process (no cost of renting premises, saving utility bills, etc.);

- a significant increase in the quality of education due to the means of electronic libraries, the use of ICT, an increase in the scale of independent work of students, listeners, etc .;

- organization of a unified (universal) informational educational environment for higher education. Based on the analysis of a significant source base, it can be stated that in the distance learning system, the defining methods of managing educational activities and methods of teaching are software and hardware that work on the basis of ICT, communication networks and systems, and are used by the subjects of the educational process (which are remote) among themselves ) under the guidance of a teacher.

So, the distance learning system of higher education is a multimedia, modular, multifunctional and hardware-software complex based on the widespread use of network and web technologies by students and teachers. In the modern global advancement of the world in general and the Ukrainian society, in particular, the Internet has to some extent transformed into an educational space, opening up great opportunities for students to access information resources and productive cooperation.

The largest platform for free online academic education today is Coursera. Here you can take hundreds of different courses from 62 universities in North America, Europe, Asia and Australia. The vast majority of universities offer courses in English, but French, Spanish, Italian, and Chinese are also available. Coursera offers courses in the following areas: Humanities and Social Sciences, Mathematics, Economics, Law, Science, Medicine, Nutrition, Music, Design, Business, Computer Science, Engineering, and others. As of March 2021, Coursera had 7.7 million registered users from all over the world.

The Udacity platform is similar in many ways to Coursera, but specializes in computer education. Of the 24 courses offered to date, most are in computer science (programming, artificial intelligence, 3D graphics, cryptography), but mathematics, physics, psychology, and entrepreneurship are also presented (Cordeiro, Marques, Costa, 2021). 
In 2006, a young American S. Khan, a graduate of the Massachusetts Institute of Technology, began creating video tutorials on mathematics for his younger cousin and uploading them to YouTube. Over time, these videos, which simply and wittily explained school material, gained immense popularity on the Internet. This is how the Khan Academy educational platform was born. Today the site contains about 4000 mini-lectures on mathematics, physics, chemistry, biology, history, economics, computer science, medicine, astronomy and art. Khan Academy is well suited not only for self-mastery of the material, but also for use by teachers who wish to supplement their curriculum. Thanks to volunteers, the video lectures on the site are translated with subtitles or dubbing into different languages of the world, including Ukrainian.

The success of open online education confirms that today millions of people around the world are striving for new knowledge. On the other hand, the proliferation of virtual forms of teaching has revealed many willing to share their knowledge and skills with others. An example of this is the Udemy platform, which allows educators to create online courses on any topic. A whole range of course creation tools are available on the platform: you can upload video and audio lectures, slide presentations, text files, as well as conduct virtual conferences. To date, Udemy hosts more than 6,000 courses in any field: various academic subjects, entrepreneurship, languages, music, art and photography, design, sports and much more. Among them are both free and paid courses.

Duolingo is a free language learning service that also acts as a crowdsourced translation platform. Its developer, L. von Ahn, sought to find a way to translate thousands of pages on the Internet without resorting to dubious machine translation or the valuable services of professional translators. His fictional system solves this problem: people translate real web content by doing language learning exercises. Now on the site you can study Spanish, French, German, Italian and Portuguese (for those who know English), as well as English (Bansak, Starr, 2021).

All of the above allows us to state: distance (or virtual) education is a change and increase in the internal qualities of real subjects (student, teacher), occurring as a result of their joint interaction (virtual educational process).

Virtual educational institutions can appear on the basis of (Kruszewska, Nazaruk, Szewczyk, 2020):

- institutions that have historically worked in the field of open and distance learning;

- traditional educational institutions without distance learning experience, thus wishing to reduce the cost of training;

- traditional educational institutions without distance learning experience, thus wishing to improve the quality of educational services, which will accordingly increase the flow of students wishing to study using modern cutting-edge technologies;

- the corporate business sector, which has internal training programs offered to the market under the name "virtual".

According to the degree of use of virtual education systems in the world, three areas can be identified.

The first includes educational institutions, all work of which is based only on Internet technologies. Through the worldwide network, everything is carried out: the choice of the course, its payment, classes with students, the transfer of test assignments and their verification, as well as the passing of midterm and final exams. Such training centers are called virtual universities, but there are not many of them yet. This direction is just beginning to be actively implemented, but the advantages of its use are indisputable.

The most numerous areas are educational institutions that combine various traditional forms of day and distance learning with technological innovations. For example, some higher educational institutions are converting part of their program courses into a virtual form, in particular, they create linguaphone classes for teaching foreign languages without a teacher. In turn, 
distance learning centers, although they rely on Internet technologies, at the same time do not abandon the practice of conducting face-to-face examination sessions. In any case, only part of the process will be computerized.

Learning centers for which the Internet serves only as an internal communication medium. They can create business card sites for themselves that post information about curricula (plans), seminars, student timetables, university news, photographs and virtual tours, as well as library catalogs. In fact, this is just an advertisement for traditional universities, which in itself does not carry any educational burden.

Today, there are two types of institutions in the world that offer a sufficiently high-quality education through a distance learning scheme - these are ordinary higher educational institutions that have a faculty of distance education and where there is an opportunity to gain knowledge in almost all disciplines or specialties studied in higher educational institutions. And educational companies that specialize exclusively in distance learning, but offer the most diverse set of areas that are in no way related to each other.

The disadvantages of distance education include (Liu et al, 2020):

- the lack of face-to-face communication between the teacher and the student, which means there is no individual approach to teaching and upbringing;

- students are not always self-disciplined, conscious and independent, as is necessary in distance learning;

- good technical equipment is required for constant access to information sources;

- lack of practical training and lack of constant monitoring;

- the need for a student to have strong personal motivation, the ability to study independently, without constant support and push from the teacher;

- the lack of the possibility of immediate practical application of the knowledge gained, followed by a discussion of the issues that have arisen with the teacher and clarification of the situation with specific examples;

- the percentage of completion of the programs is quite low, given that tens of thousands of people enroll in online courses. This is partly due to the fact that such a process requires personal discipline. Also, online education is mostly not recognized by official institutions;

- low theoretical study of the problem of distance learning. This is manifested primarily in the absence of clearly defined learning goals and the necessary initial requirements for a student to work in this system,

- a weak level of the control system of his knowledge, the absence of requirements for the content of distance courses and educational and methodological support, copyright protection of developers of educational materials, certification of distance education institutes, etc. And, besides, it is not possible to train specialists in all specialties with the help of distance courses.

The presence of these shortcomings forms a stable trend towards blended learning with an improvement in the epidemic situation, but with a permanent awareness of the fact of the introduction of the distance education system on a permanent basis.

By blended learning, it is customary to mean the combination of formal learning tools classroom work, the study of theoretical material - with informal, for example, dialects using e-mail and Internet conferences. The blended form of education organically combines both daytime and distance learning forms.

Comparative characteristics of distance and blended learning are shown in table 2. 
Table 2. Comparative characteristics of distance and blended learning.

\begin{tabular}{|c|c|c|c|}
\hline \multicolumn{2}{|c|}{ Distance learning } & \multicolumn{2}{|c|}{ Blended learning } \\
\hline $\begin{array}{c}\text { one-way } \\
\text { communication }\end{array}$ & $\begin{array}{l}\text { the structure of the } \\
\text { course is hidden from } \\
\text { the learner or student }\end{array}$ & $\begin{array}{c}\text { two-way } \\
\text { communication }\end{array}$ & $\begin{array}{c}\text { student or student is } \\
\text { active, active, involved in } \\
\text { educational } \\
\text { process }\end{array}$ \\
\hline $\begin{array}{l}\text { the student or student } \\
\text { is passive, inactive, he } \\
\text { is an outside observer }\end{array}$ & $\begin{array}{l}\text { the text of the lectures } \\
\text { is written dryly and } \\
\text { impersonally }\end{array}$ & $\begin{array}{l}\text { the learner or student } \\
\text { is familiar with the } \\
\text { course structure }\end{array}$ & $\begin{array}{l}\text { the learner or student is } \\
\text { under supervision }\end{array}$ \\
\hline $\begin{array}{l}\text { the student almost } \\
\text { does not apply } \\
\text { knowledge and skills }\end{array}$ & $\begin{array}{l}\text { tasks are given only at } \\
\text { the end of the chapter }\end{array}$ & $\begin{array}{l}\text { the text of the tutorial } \\
\text { is written in a friendly } \\
\text { and encouraging } \\
\text { manner }\end{array}$ & $\begin{array}{l}\text { the learner or student } \\
\text { applies the acquired } \\
\text { knowledge and skills }\end{array}$ \\
\hline $\begin{array}{l}\text { the text is divided into } \\
\text { chapters and chapters }\end{array}$ & $\begin{array}{l}\text { control tasks are not } \\
\text { provided }\end{array}$ & $\begin{array}{l}\text { tasks and exercises for } \\
\text { placement throughout } \\
\text { the text }\end{array}$ & $\begin{array}{l}\text { the text is divided into } \\
\text { small sections }\end{array}$ \\
\hline \multicolumn{2}{|c|}{$\begin{array}{l}\text { the student or student cannot receive feedback } \\
\text { on their progress }\end{array}$} & envisaged control tasks & $\begin{array}{l}\text { the student or student } \\
\text { receives feedback on their } \\
\text { progress }\end{array}$ \\
\hline
\end{tabular}

Blended study consists of three stages (Langegard, Kiani, Nielsen, Svensson, 2021):

1. Remote research of theoretical material.

2. Mastering the practical aspects in the form of day classes.

3. The last phase - passing the exam or completing the final work.

A blended learning model is a model for using distributed information and educational resources in stationary learning using elements of asynchronous and synchronous distance learning. It is practiced as an element of stationary education when conducting classroom studies and students' independent work. That is, blended learning inherits the advantages of distance learning and eliminates its disadvantages. Blended learning uses a wide variety of methods, both traditional and interactive: laboratory lectures, computer-based presentations, computer-assisted learning and online learning.

The results of the student survey made it possible to identify the difficulties and advantages of the introduced distance learning during the coronavirus pandemic, among the disadvantages of which (Ferraro, Ambra, Aruta, lavarone, 2020):

- technical problems that have arisen due to the lack of technical communication capabilities of users, the lack or low speed of Internet access of personal computers for students living in rural areas;

- psychological problems, where students noted the lack of live communication between the teacher and the student, between fellow students for the exchange of experience, a significant increase in tasks, lack of time to complete them, limited access to a computer, since some family members were also transferred to remote work.

Teachers, on the other hand, noted the impossibility of individual counseling of students, an increase in the time for correspondence with students, since online classes involve a more detailed description of homework than usual for the audience. Academic staff have also experienced a significant onslaught from COVID-19, as the pandemic has brought about the greatest and fastest transformation of teaching and assessment ever seen in modern universities.

This led to an increased workload on academic staff and required colleagues to pool their own efforts, including software training and joint practice. A specific disadvantage of distance learning for teachers has become a "round-the-clock load" due to the need to create updated materials specifically for online classes, post them on resources, conduct consultations and videoconferences, maintain contact with students (special attention is required to the order of the 
teacher's actions in case of a long absence of a student, who does not attend classes and does not make contact), as well as monitor and assess the level of knowledge. A separate loading point for teachers was the increased number of reporting documents during distance learning. Correcting grades in the shortest possible time led to great difficulties, and organizing exams online became a test of discipline, clarity and thoroughness. The combination of working from home and supervising homework with other household responsibilities has blurred the lines between work and household chores and led to longer working hours and greater workload. COVID-19 has largely made major adjustments to the clarity and timeliness of feedback from stakeholders, especially students and staff.

One of the most rewarding benefits of adapting to COVID-19 has been the success of Zoom's online Q\&A sessions that provide employees with comprehensive answers to how universities respond in times of crisis. Communication with the students was somewhat more difficult due to their personal ways of learning and the need to provide them with ongoing support and advice. But there is a conviction that the future belongs to remote technologies.

Experience shows that students remotely, more adapted to external conditions, they are independent, sociable and communicative, confidently make important decisions, so it will be easier for them to get used to the changes in the modern world of management technologies. At the same time, as noted by teachers and students in the survey, the quality of distance education is not inferior to the quality of teaching face to face. Among the positive aspects of using distance learning is the development of discipline and self-organization, which allows you to get education at a convenient time and place and equal access to education, regardless of place of residence, health or social status. Teachers indicate their renewed role, they become mentor-consultants, coordinating the learning process, constantly improving their own courses and skills (El Refae, Kaba, Eletter, 2021).

It was pleasant to observe the scale, speed and quality of colleagues' adaptation to new circumstances and a positive attitude towards experiments with new ways of interaction between teaching and research. The variety of alternative ways of providing student learning assistance, the creativity of colleagues in developing new forms of assessment and learning support, and the willingness of staff to introduce new technologies have provided a positive impact on the educational process as a whole. COVID-19 has accelerated and reinvigorated continuing pedagogical trends, creating a natural experiment in which numerous innovations are tested and evaluated. Early indications suggest that many of the innovations applied during a pandemic will benefit students after a crisis.

Thus, as our experience and research shows, distance learning can quickly adapt to the requirements of the information society and prepare a future specialist. In combination with traditional forms, distance education in a higher educational institution can provide a wide range of educational services for both applicants and students to acquire the necessary skills and abilities for future professional activities, and for teachers in order to improve their qualifications.

The main directions and recommendations for improving the quality of distance education and student motivation can be identified (Gillett-Swan, 2017):

- improvement of the state of Internet networks in the country;

- formation of a unified strategy of higher education institutions for the formation of an organizational model of distance learning;

- continuous development and modernization of the material base of distance learning, equipment, computer and software, attracting specialists in the field of information technology;

- ensuring the functioning of a single platform for the introduction of distance learning;

- continuous improvement of the methodological and digital skills of distance learning teachers, the creation of a sufficient number of full-fledged distance courses with high-quality 
content and the improvement of the system for assessing the level of mastering the knowledge and skills of students.

It is a systematic comprehensive approach to the organization of distance learning that will ensure its effectiveness in modern conditions.

\section{CONCLUSION}

So, distance learning technologies have already taken one of the leading places in modern education, given the difficult pandemic circumstances. Interest in obtaining a specialty remotely is growing, and the qualitative characteristics of specialists differ only in positive aspects: selfconfidence, easy adaptation in a team, and the ability to self-study. At the same time, distance learning technologies can be viewed as a natural stage in the evolution of the traditional education system from a blackboard with chalk to an electronic board and computer learning systems, from a book library to an electronic one, from an ordinary classroom to a virtual one. The effectiveness of distance learning is based on the fact that learners themselves feel the need for further learning, and are not subject to pressure from outside. They have the opportunity to work with educational materials in such a mode and a volume that suits them directly. The effect largely depends on how regularly the student is engaged. Consistent implementation of control and diagnostic tasks and graduation work, as well as support on all issues from the coordinating teacher ensures the systematic assimilation of knowledge.

Open education in many countries is considered today as a system that provides nationwide access to educational resources through the widespread use of information educational technologies of distance learning and, on this basis, provides conditions for the fullest realization by citizens of their rights to education, which in terms of structure and quality meets the requirements of economic development. and civil society.

Authors' Contributions: Sybirna, R.: conception and design, acquisition of data, analysis and interpretation of data, drafting the article, critical review of important intellectual content; Polishchuk, G.: conception and design, acquisition of data, analysis and interpretation of data, drafting the article, critical review of important intellectual content; Balanutsa, O.: conception and design, acquisition of data, analysis and interpretation of data, drafting the article, critical review of important intellectual content; Marchuk, A.: conception and design, acquisition of data, analysis and interpretation of data, drafting the article, critical review of important intellectual content. All authors have read and approved the final version of the manuscript.

Ethics Approval: Not applicable.

Acknowledgments: Not applicable.

\section{REFERENCES}

Ana, A., Minghat D., Purnawarman P., Saripudin S., Muktiarni M., Dwiyanti V., and Mustakim S. (2020) "Students' Perceptions of the Twists and Turns of E-Learning in the Midst of the Covid 19 Outbreak." Revista Romaneasca Pentru Educatie Multidimensionala 12 (1): 15-26. https://doi.org/10.18662/rrem/12.1sup2/242

Arora, A. K., \& Srinivansen, R. (2020). Impact of pandemic COVID-19 on the teaching-learning process: A study of higher education teachers. Parabandhan: Indian Journal of Management, 13(4), 43-56.

https://doi.org/10.17010/pijom/2020/v13i4/151825

Volchik,V. (2019). Institutional Traps in the Education and Science Sector under the Conditions of Optimisation. Terra Economicus, 17(2), 146-162. https://doi.org/10.31063/2073-6517/2019.16-4.14

Welch, A. (2001). Globalisation, Post-modernity and the State: Comparative education facing the third millennium. Comparative Education. 37. https://doi.org/10.1080/03050060120091265

Bansak, C. \& Starr, M. (2021). Covid-19 shocks to education supply: how 200,000 U.S. households dealt with the sudden shift to distance learning. Review of Economics of the Household. https://doi.org/10.1007/s11150-020-09540$\underline{9}$ 
Burkina N. (2014) Self-realization of a teacher of higher education and distance learning. Computer at school and family. 2№ 4. P. 39-41.

Cordeiro, E. de P. B., Marques, M. M. C., \& Costa, M. T. N. (2021). Socio-emotional education: paths to inspire studies, research and practices. Revista Tempos E Espaços Em Educação, 14(33), e13729.

https://doi.org/10.20952/revtee.v14i33.13729

El Refae, G.A., Kaba, A. and Eletter, S. (2021), "Distance learning during COVID-19 pandemic: satisfaction, opportunities and challenges as perceived by faculty members and students", Interactive Technology and Smart Education, Vol. ahead-of-print No. ahead-of-print. https://doi.org/10.1108/ITSE-08-2020-0128

Filipenko T. (2016) Internet technologies in distance learning as an innovative form of legal education. BusinessInform. № 8. P. 253- 255.

Ferraro, F. \& Ambra, F. \& Aruta, L. \& lavarone, M. (2020). Distance Learning in the COVID-19 Era: Perceptions in Southern Italy. Education Sciences. 10. https://doi.org/10.3390/educsci10120355

Gillett-Swan, J. (2017). The Challenges of Online Learning: Supporting and Engaging the Isolated Learner. Journal of Learning Design, 10(1), 20-30. https://doi.org/10.5204/ild.v9i3.293

Ivanov S. (2012) The system of distance education in Ukraine: current directions of development. Humanities. science. №2. pp. 12-19.

Kruszewska A., Nazaruk S. \& Szewczyk K. (2020) Polish teachers of early education in the face of distance learning during the COVID-19 pandemic - the difficulties experienced and suggestions for the future, Education 3-13. https://doi.org/10.1080/03004279.2020.1849346

Langegard, U. \& Kiani, K. \& Nielsen, S. \& Svensson, P. (2021). Nursing students' experiences of a pedagogical transition from campus learning to distance learning using digital tools. BMC Nursing. 20. https://doi.org/10.1186/s12912-021$\underline{00542-1}$

Liu, J., Bao Y., Huang X., Shi J., and Lu L. (2020) “Mental Health Considerations for Children Quarantined Because of COVID19." The Lancet Child \& Adolescent Health May; 4 (5): 347-349. https://doi.org/10.1016/S2352-4642(20)30096$\underline{1}$

Received: 31 August 2021 | Accepted: 22 October 2022 | Published: 18 January 2022

This is an Open Access article distributed under the terms of the Creative Commons Attribution License, which permits unrestricted use, distribution, and reproduction in any medium, provided the original work is properly cited. 